\title{
University of the Arctic's Thematic Network on Arctic Engineering and Science
}

\author{
H. Zubeck ${ }^{1}$, S. Knutsson ${ }^{2}$ P. Erland Jensen ${ }^{3}$ and M. Holtegaard Nielsen ${ }^{3}$ \\ ${ }^{1}$ Professor, University of Alaska Anchorage, School of Engineering, 3211 Providence \\ Drive, Anchorage, AK 99508; PH (907) 786-1900; email: afhkz@uaa.alaska.edu \\ ${ }^{2}$ Luleå University of Technology, Universitetsområdet, Porsön, 97187 Luleå, \\ Sweden; email: Sven.Knutsson@ltu.se \\ ${ }^{3}$ Assistant and Associate Professors, Technical University of Denmark (DTU), \\ ARTEK (Centre of Arctic Technology), Department of Civil Engineering, Bygning \\ 204, 2800 Lyngby, Denmark; Email: pej@byg.dtu.dk,mhn@byg.dtu.dk.
}

\begin{abstract}
The Thematic Network in Arctic Engineering and Science (TN AES) was created In June 2008 when it was approved by the University of the Arctic's Council. The TN AES focuses on the development of sustainable technologies through engineering and science in the Arctic. The goals of the TN AES are twofold: The main goal is to improve the quality of life and allow the development of natural resources in the arctic through innovations in technologies used in the construction, maintenance and operation of infrastructure, housing, public/private facilities and equipment. The other goal is to assess the impact of climate change on these technologies. This paper introduces briefly the University of the Arctic to the engineering community and then describes current and planned network activities, such as joint education programs.
\end{abstract}

\section{INTRODUCTION}

The University of the Arctic (UArctic) is a cooperative network of 116 universities, colleges, and other organizations committed to higher education and research in the North (UArctic, 2009). The members of the UArctic share resources, facilities, and expertise to build post-secondary education programs that are relevant and accessible to northern students. The overall goal is to create a strong, sustainable circumpolar region by empowering northerners and northern communities through education and shared knowledge. The University of the Arctic recognizes the integral role of indigenous peoples in northern education, and seeks to engage their perspectives in all of its activities. Figure 1 illustrates the extensiveness of the member institutions around the circumpolar North.

The purpose of this paper is to describe the UArctic Programs and introduce the Thematic Network in Arctic Engineering and Science to the northern engineering educators, students and engineers.

\section{UARCTIC PROGRAMS}

UArctic's programs are focussed around six strategic areas: Undergraduate Studies, Graduate Studies, Mobility, Access, Knowledge and Dialogue and Thematic 
Networks (UArctic, 2009). The programs include higher education curricula, opportunities for student and faculty mobility as well as dialogue and discussion and innovative programs for solving some of the unique challenges to offering higher education in the North. The specific programs are summarized in Table 1.

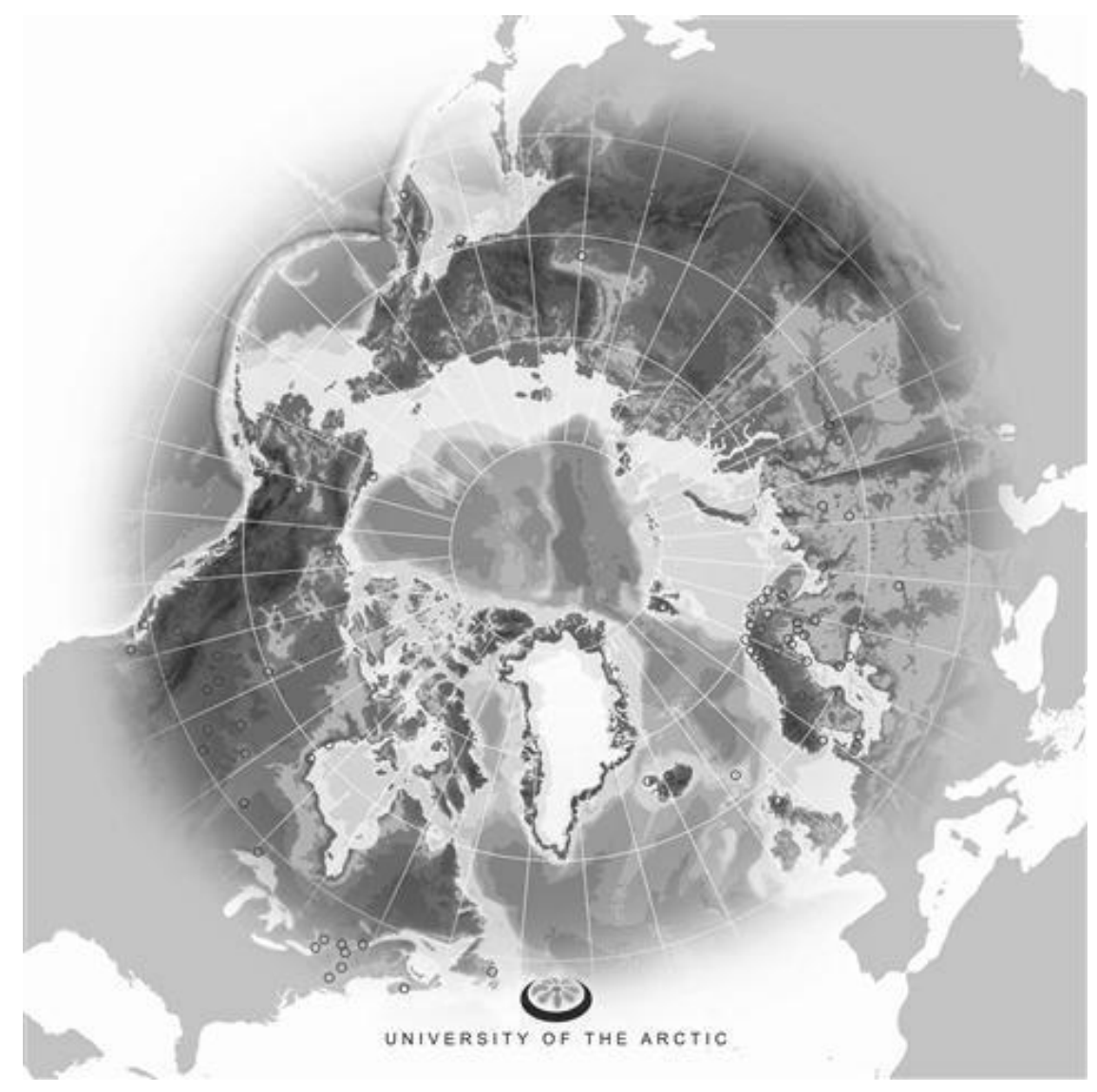

Figure 1. University of the Arctic Member Institutions.

Table 1. University of the Arctic Programs (adapted from UArctic, 2009).

\begin{tabular}{|lll|}
\hline Program & $\begin{array}{l}\text { Strategic } \\
\text { Area }\end{array}$ & Description \\
\hline GoNorth & Mobility & $\begin{array}{l}\text { Offers opportunities for students from the south to go } \\
\text { study at a northern higher education institution and } \\
\text { experience life in the Circumpolar North. }\end{array}$ \\
NorthTREX & Mobility & $\begin{array}{l}\text { Northern Teaching Resources Exchange program } \\
\text { provides opportunities for northern teachers to gain } \\
\text { circumpolar experiences and perspectives, and } \\
\text { strengthen northern institutions abilities to share } \\
\text { faculty resources. Mobility in this program normally } \\
\text { lasts for }<3 \text { months. }\end{array}$ \\
Graduate & $\begin{array}{l}\text { Graduate } \\
\text { Networks }\end{array}$ Studies & $\begin{array}{l}\text { Promotes regional cooperation and identity among } \\
\text { advanced students and builds an academic community }\end{array}$ \\
\hline
\end{tabular}




\begin{tabular}{|c|c|c|}
\hline & & $\mathrm{am}$ \\
\hline north2north & Mobility & $\begin{array}{l}\text { Provides opportunities for students to experience } \\
\text { different northern regions by allowing students to study } \\
\text { at other UArctic institutions. }\end{array}$ \\
\hline $\begin{array}{l}\text { Circumpolar } \\
\text { Studies }\end{array}$ & $\begin{array}{l}\text { Under- } \\
\text { graduate } \\
\text { Studies }\end{array}$ & $\begin{array}{l}\text { Delivers courses online about the Circumpolar World, } \\
\text { Land and Environment, Peoples and Cultures and other } \\
\text { issues. }\end{array}$ \\
\hline $\begin{array}{l}\text { UArctic } \\
\text { Field School }\end{array}$ & $\begin{array}{l}\text { Graduate } \\
\text { Studies }\end{array}$ & $\begin{array}{l}\text { Integrates short, thematically focused courses that } \\
\text { provide training for young researchers from member } \\
\text { institutions. }\end{array}$ \\
\hline $\begin{array}{l}\text { Open } \\
\text { Learning }\end{array}$ & Access & $\begin{array}{l}\text { Gives northerners outside the traditional university } \\
\text { structure opportunities to further their education and } \\
\text { training. Offers shorter courses than the BCS program, } \\
\text { and has more emphasis on practical courses and skills } \\
\text { training. }\end{array}$ \\
\hline $\begin{array}{l}\text { Northern } \\
\text { Research } \\
\text { Forum }\end{array}$ & $\begin{array}{l}\text { Knowledge } \\
\text { and } \\
\text { Dialogue }\end{array}$ & $\begin{array}{l}\text { Provides a platform for policy-relevant discussion and } \\
\text { the sharing of research on northern issues. Holds } \\
\text { biennial meetings with the participation of scientists, } \\
\text { policy makers and representatives of other } \\
\text { stakeholders. }\end{array}$ \\
\hline $\begin{array}{l}\text { Thematic } \\
\text { Networks }\end{array}$ & & $\begin{array}{l}\text { Encourage faculty and institutional cooperation on } \\
\text { subjects of shared interest among UArctic members. } \\
\text { Aim at cooperation, sharing of resources, and provides } \\
\text { avenue for UArctic activities. This includes student and } \\
\text { faculty exchange, joint curriculum and degree } \\
\text { development and research. }\end{array}$ \\
\hline $\begin{array}{l}\text { Mimir } \\
\text { Research } \\
\text { Outreach } \\
\text { Program }\end{array}$ & $\begin{array}{l}\text { Knowledge } \\
\text { and } \\
\text { Dialogue }\end{array}$ & $\begin{array}{l}\text { UArctic is involved in two major international Arctic } \\
\text { research events: the 2nd Intl. Conf. on Arctic Research } \\
\text { Planning (ICARPII) and the International Polar Year } \\
\text { (IPY). Mimir's primary responsibility is to plan and } \\
\text { coordinate the outreach portion of UArctic's } \\
\text { participation in both ICARPII and IPY. }\end{array}$ \\
\hline
\end{tabular}

\section{THEMATIC NETWORK IN ARCTIC ENGINEERING AND SCIENCE}

The Thematic Network in Arctic Engineering and Science (TN AES) was recently established as the UArctic Council accepted the proposal for the network in its June 2008 meeting. The host institutions are Luleå University of Technology (LTU), Sweden and the University of Alaska Anchorage (UAA). The Arctic Technology Centre (ARTEK) of the Technical University of Denmark (DTU) holds the TN AES secretariat. Other members supporting the proposal included

- $\quad$ Rovaniemi University of Applied Sciences, Finland

- $\quad$ Arkhangelsk State Technical University, Russia

- $\quad$ University of Oulu, Finland

- $\quad$ Komi State Pedagogical Institute, Russia 
- University of Stockholm, Sweden.

Other UArctic member institutions are invited to join the efforts. Figure 2 presents participants of the first planning meeting of the network in May 2008.

The TN AES will focus on development of sustainable technologies through engineering and science that improve the quality of life and allow for natural resource development (mining, oil and gas development, forestry etc.) in the north while preserving the environment.

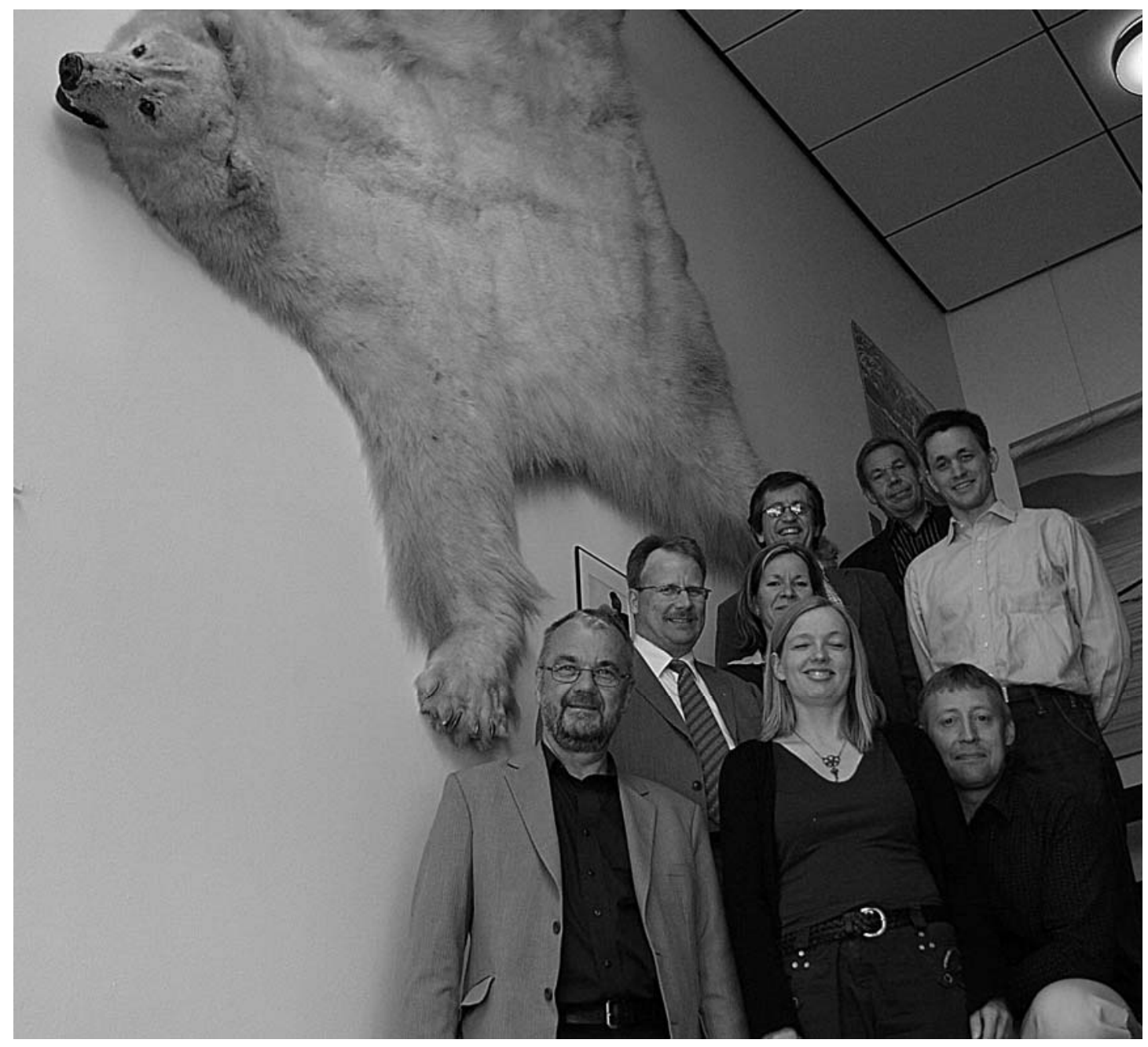

Figure 2. Arctic Engineers planning thematic network activities at the ARTEK.

Rationale. The communities in the north depend like other communities on the reliable infrastructure, such as transportation and communications systems, energy delivery, water and wastewater systems. Comfortable housing, adequate education, health care as well as other public facilities are important to the quality of life in the arctic. Exploration and development of natural resources, such as mines, oil and gas fields, also depend on the reliable infrastructure and new waste handling and remediation technologies. Further, the role of risk and environmental assessments, as 
well as response readiness to incidents has become increasingly important. What makes living and industrial development in the arctic challenging is the fact that the technical demands for construction, maintenance, logistics and operation of the arctic facilities differ from the demands in the more temperate regions. Factors causing the difference include cold climate (ice, snow, frost, presence of permafrost, cold working environment, light and darkness, etc), sparse population, limited transportation modes, long distances, socio-cultural issues, sensitive environment and often limited funding sources. Technologies applied successfully in southern regions do not necessarily work in the north at all, or need modifications. Therefore the northern people need to do its own research and transfer the acquired knowledge through education and outreach projects. Further, in the context of climate change northern people are facing new challenges. Old transportation routes, poorly performing winter roads, lack of snow, increased coastal erosion, sea ice retreat, degrading permafrost etc. are causing new challenges for northern people. Knowledge of what is functioning well in northern societies has to be reassessed in relation to a changing climate. These challenges have to be faced and dealt with in order to have functioning and sustainable societies in the north. Despite all of the aforementioned work to be done, the educational institutions struggle with the lack of expertise as well as number of students to support sustainable educational programs in the fields of engineering and science focused on the arctic conditions.

Goals. Thus, the goals of the TN AES are to:

1. Enhance the innovations in technologies used in the construction, maintenance, logistics and operation of infrastructure, housing, public/private facilities, vehicles, machinery and equipment in order to improve the quality of life and allow the development of natural resources in the arctic.

2. Process studies to understand climate change in the arctic and using climate models to make projections of future climate change in the arctic.

3. Assess the impact of climate change on technologies used in the construction, maintenance and operation of infrastructure, housing, public/private facilities and equipment.

The innovations in technologies as well as the climate change assessments consider human, economic, socio-cultural as well as ecological aspects throughout the lifetime of the product/facility. The goal is achieved by creating a network among the member institutions that provides an adequate number of students and specialized faculty to allow sustainable education and research programs in the area of arctic science and engineering.

Planned activities. The planned activities include research cooperation, joint education programs, curriculum development, knowledge sharing, teacher education and outreach. The UArctic programs, such as northTREX faculty exchange and north2north student exchange, as well as distance education via e-learning are utilized for educational programs. The following sections describe some current and planned activities. 
Online courses in the field of Arctic Engineering are offered by the University of Alaska Anchorage. Students are able to earn Masters of Science degree in Arctic Engineering in online environment - from the comfort of their offices or homes. Upper level undergraduate and graduate engineering students from around the world are eligible for enrollment.

Current core courses include Introduction to Arctic Engineering, Frozen Ground Engineering, Ice and Snow Engineering, Arctic Hydrology \& Hydraulic Engineering, Arctic Utility Distribution and Arctic Heat \& Mass Transfer. In addition students may take elective courses either on-line or in classroom. Each course includes learning modules with presentations, homework assignments, exams and a virtual conference (Smith, 2002, Zubeck, 2007). The degree includes a research project involving arctic engineering issues.

Among the graduates is an international student, Sergei Baranof, who graduated in two years taking courses from Russia, United Kingdom and Texas, U.S.A. - literally around the world. While working as a senior engineer, Sergei states that "UAA's Arctic Engineering courses helped me to develop my expertise week by week, allowing me to find better technical solutions and cut the costs of projects that I was coordinating." The UAA hopes to have more national and international students, as well as educators, through the UArctic, taking the entire program or a few courses.

International Semester in Greenland (ISG) is another interesting TN AES cooperation project to be hosted by the ARTEK. It is also open to university students from around the world. In 2010, the ISG is aiming to provide the students with basic and advanced skills within the topics:

- Light and passive constructing methods

- Exploitation and disposal methods for biogenic waste

- Renewable and accessible energy.

The semester is comprised of lectures, exercises, project work, and work in the field. A major project of the individual student's choice within one or more of the above topics is a part of the studies. Assessment will be based on presentations, essays, and reports.

Teaching is performed by faculty members and scientists from the DTU and collaborating institutions including the UArctic. On on-going research activities in Sisimiut, Greenland such as the Low Energy House, the newly installed solar heating plant, the Democratic Sustainability project in the settlement of Sarfannguaq, waste water treatment plants, are incorporated in the curriculum. All activities will be offered in English. All students holding a Bachelor degree in science or technology, or engineering from an accredited university are eligible. Students will earn 30 ECTS points during the semester that starts at the end of January and ends at the end of May. The students will spend the first four weeks at the DTU in Copenhagen. These weeks include week of orientation and introduction, and three weeks of studying the curriculum material. The rest of the ISG, about 13 weeks, will take place in Greenland, in Sisimiut and at the project work location (if outside Sisimiut). More information about this program can be found at ARTEK, 2009. 
Arctic Camps are part of the LTU's arctic engineering training. The camps together with laboratory and full scale design, construction and analysis of snow structures give students the benefit of going to a Northern University. According to Sven Knutsson, it does not pay to report problems and challenges of cold regions at every opportunity. Instead, the snow, ice and cool climate are gift from above and need to be appreciated and used to our benefit. The arctic environment is perceived as "exotic" in the warmer climates. Recognition of this fact and its use in advertisements would bring more students to the North.

Snow and ice as an engineering material need to be included in the curriculum of the Northern Universities. Instead, more often, the Northern Universities teach their students in the same way as any other university, failing to recognize the niche market. Basic material properties can be taught using ice and snow in the experiments and thereby utilizing the local unique resources. Full scale snow/ice structures can be designed, built, instrumented and analyzed - a comprehensive learning experience.

The camps in the wild in January, the coldest time of the year, create an experience about arctic survival and arctic work environment that the students are not to forget. The Swedish military is cooperating with the LTU by equipping the students with the winter gear and guiding the expeditions. The students who participated on these arctic camps are proud of their achievement as survivors and alas, respected by their peers.

\section{CONCLUSION}

One of the UArctic's youngest thematic networks, Thematic Network in Arctic Engineering and Science, provides means for cooperation between northern engineering institutions. All institutions offering education in engineering and science are encouraged to participate in the TN AES activities.

\section{REFERENCES}

ARTEK (2009). "International Semester in Sisimiut, Greenland." $<$ http://www.artek.byg.dtu.dk/Uddannelse/International\%20Semester.aspx. $>$ (Feb. 9. 2009)

Smith, O. (2002). “Teaching Arctic Engineering Online.” Proc. $11^{\text {th }}$ Intl. Conf. on Cold Regions Engineering, ASCE, Reston, VA.

UArctic (2009). "Welcome to the University of the Arctic." http://www.uarctic.org/Frontpage.aspx?m=3 (Feb. 9. 2009).

Zubeck, H. (2007). "Use of Virtual Paper Conference as Learning Tool in On-line Courses." Proc. $8^{\text {th }}$ Intl. Symp. on Cold Region Development, Finnish Association of Civil Engineers RIL, Helsinki, Finland. 